УдК 81 '1+001.4+81'373.46

Ya. H. Mar'yanko,

Candidate of Philology,

Associate Professor of Department of foreign languages

Odesa State Academy of Civil Engineering and Architecture,

4 Didrihsona st., Odesa, 65029, Ukraine,

tel.: +380487233342,

maryanko.yanina@gmail.com

O. Yu. Zaytseva,

Candidate of Philology,

Associate Professor of Foreign Languages Department

Odesa State Academy of Civil Engineering and Architecture, 4 Didrihsona st., Odesa, 65029, Ukraine, tel.: +380487233342

\title{
UKRAINIAN DESIGN AS A SEPARATE BRANCH OF ARTS AND CRAFTS AND FORMATION OF ITS TERMINOLOGY
}

\begin{abstract}
Summary
It is impossible to investigate any terminology without the study of this branch origin, its history, characteristic features. The Ukrainian design terminology is the integral system of linguistic units; there are design names and nominative elements from other related branches (building, architecture, art) among them. The terminology of the design is characterized by a long history of development, which increases the importance of studying its terms, and today it remains the subject of in-depth enoho study.

Key words: term, terminology, scientific and technological terminology, term system, design.

Today, the flow of scientific and technical information that contributes to the development of technical terminology dramatically increases; therefore, the full study of the Ukrainian language vocabulary and the ways of its formation, as well as the study of many linguistic problems
\end{abstract}


without a comprehensive analysis of Ukrainian scientific and technical terminology, can not be considered complete.

In order to understand the peculiarities of the Ukrainian design terminology formation, we must make a brief excursion into the history of design in general, to consider extralinguistic and linguistic factors that influenced the development of its terminology.

The art of design in the historical and cultural aspect was the subject of increased attention of many scholars who considered the design problems, the integration of art and technology, the connection of design and decorative arts, the definition of aesthetic qualities. Until now there is no consensus about the reasons for the appearance and the exact period of design formation as a profession. The oldest date - more than 100 years old - is defined in the English language by the connection of arts and crafts, the greatest figure of which was a theorist of art, public figure and artist-practitioner W. Morris. It was then, in the 70's and 80's of the XIX century, within the framework of this movement, the main provisions of the theory and the principles of design, the concept of the subject environment were formulated. According to another point of view, the origin of the design is associated with the beginning of the twentieth century. Due to the fact that the artists occupied leading positions in certain spheres of industrial production, a symbiosis of artistic works of the subject environment of the future and new technical forms emerged, which, entering the spontaneously developing material environment, acquire the qualities of artistic, stylistic forms [2].

Obviously, the design as a separate branch started to exist from the moment when the first graduate specialists were released; schools, their teaching methods, the circle of teachers who could outline the limits of their profession were formed. It falls on the 20's of the twentieth century, when there appeared Russian high art and technical workshops and the Bauhaus school, which produces specialists in the field of subject-space arts, opened in Germany.

There are 5 stages of design formation in the historical and artistic aspect. I stage (XVIIth - XVIIIth centuries) - the period of integration and disintegration of art and technology at the level of artistic craft technologies, mechanical combination of technical form and aesthetic surface. By the 
XVIIth century the prototype of technology was mostly nature. The artisan production existed without any changes until the end of the Middle Ages, when the machine-tool production came to replace the craft industry.

II stage (XIXth-XXth centuries) became the period of the integral process of reproduction of the objective world: a) XIXth century - the stage of functionalism of technical constructions; gradual creation of the conditions for the implementation of the ideas of designers in speeches; $b$ ) the end of the XIXth - XXth century - the stage of the movement for the art renovation; the dominant line of design activity formation in Ukraine lay through the engineering and technical environment; c) the beginning of the XXth century - the stage of identifying the aesthetic and technical, the artistic and utilitarian in design. It was a period of peculiar aesthetic asceticism, the search for new principles of formulation on the basis of the structural and functional characteristics of the product or architectural element.

III stage (20-30's of the XXth century) - the formation of the functionalism principles. Relying on the aesthetics of functionalism, the theorists and practitioners of the „Bauhaus“ put forward the principle of the unity of form and function. A special art-study approach requires the development of design in Ukraine in the 20-30's. It is important to draw attention to the heterogeneity of the theory and practice of design in Ukraine in the Eastern and Western Ukraine, which had a great influence on the formation and development of Kiev and Kharkiv design schools that were formed under the influence of Russian designers' art. As a result, the number of printed Ukrainian-language products in design decreased.

IV stage (30-90's of the XXth century) - the stage of rationalistic functionalism and polarization of the project activity. The new situation in the domestic art is actually in the middle of the 1980s, when the artistic life of the Soviet Union is going through a boom, when political leaders announce a course to rebuild the Soviet society in the field of cultural life. There is a distinction between the areas of professional interests between architectural and design schools. It is interesting that, until the 1960's, domestic dictionaries did not include the definition of „design“" at all. There are positive effects of the activities of the new design associations that arose after the Second World War, the first designer literature appears. 
V stage (the end of XXth century - the beginning of XXIth century) the stage of the author's design, creation of the author's collections and models. XXth century gave a lot of useful designs, because it was during this century, the design was finally formed into an independent kind of professional activity. It should be noted that during this period a conscious formation of Ukrainian terminology of design began by accumulating terminological material, laying the theoretical foundations of the codification of the design terminology. The processes of establishing the Ukrainian terminology of design are evidenced by the works of such authors as: E. Antonovich, M. Stakunkych, V. Danilenko, S. Migal, M. Selivachov, P. Tatievsky, V. Torkatyuk, L. Khominsky, O. Shypanov, V. Shcherbak, O. Polishchuk, Y. Legenky, T. Malik, O. Khmelovskiy.

The formation and development of Ukrainian terminology of design are closely connected with the history of the development and formation of the field of design as a separate science and the Ukrainian literary language in general. In our opinion, the stages of development of Ukrainian terminology of design are related to the stages of formation of Ukrainian scientific and technical terminology in general, since the terminology studied by us is an integral part of it. In view of this, we distinguish the following periods of formation of the Ukrainian terminology of design: 1) XVIIIth - the beginning of XIXth century; 2) the second half of the XIXth - beginning of the XXth century; 3) 20-30's of the XXth century; 4) 40-90's of the XXth century; 5) modern period.

The first stage of the development of the UDD (XI-XIX centuries) is ,pre-scientific". This is the period of origin of the specified terminology; qualify it as the initial one; it has $57 \%$ of the terms in such lexical-thematic groups as: special names of ornaments (16\%), special names of decor (14\%), special names of small architectural forms (14\%), special names of ornaments $(12 \%)$, building elements $(12 \%)$, special names of tools (10\%): special names of technological processes $(8 \%)$, special names of materials $(6 \%)$, special names of design technicians $(4 \%)$, special names of elements of landscape design $(4 \%)[7 ; 8 ; 9 ; 10 ; 11]$.

Cultural-historical approach to the formation and development of design is important in the context of the development of Ukrainian design 
education. Based on the analysis of historical theoretical sources, it was revealed that prophedevic design education in pagan Ukraine was a religion that contributed to solving complex state, political, economic, scientific, cultural and domestic problems. The form of propaedeutic design education in the conditions of the pagan culture of Ukrainians was a Christian culture, and another aspect of the empirical experience of Ukrainian design education was traditional ritual holidays. In addition, one of the first building schools was created in the Pechersk Monastery in the XIth, then (the end of the XIth - the beginning of the XIIth century) two more architectural schools appeared: Halytska and Pereyaslavska, where education and production were based on the direct transfer of mastery from a teacher to a student.

Soon Kyivska Rus appeared; during the 3 centuries of its existence the art and technique of Kyivska Rus achieved a high level at that time. Decorating in the form of ornaments and other decorations explains the ideological principles of our ancestors. The Ukrainian hut was a model of the nature-related organization of the subject-spatial environment and was a synthesis of ,substantially expressed arts at the level of functional technologies of its time“ [3].

The second stage (XIXth - XXth centuries) is associated with the conscious formation of design as an industry and its terminology. The development of artistic and industrial education in Ukraine was conducted in accordance with the social, political and economic circumstances of the contemporary life. The centers of folk art became the basis for the founding of the first educational establishments. Thus, in Kharkiv (1767), classes of painting, painting and architecture were founded, which later (1805) became a part of Kharkiv University. In 1844 the „Technical Academy“ was opened, which became the beginning of design education in Lviv. In 1920 the Department of Architecture and Construction was opened in Lviv Polytechnic. At the beginning of the XXth century Free Academy of Arts was founded in Lviv, where the aim of the institution was to strive for the versatility of artistic expression in various arts - architecture, graphics, design, painting, sculpture and applied arts. The beginning of deliberate creation of the terminology of design (6\%) falls on the second half of the 
XIXth century, when new ideas, forms and styles were developed. Most of the terms of this period are special names of landscape design elements, special names of ornaments, special design terms.

With the industrial revolution at the end of the XIXth century there appeared a design that replaced the man-made thing with the object of industrial production. The separation of technology took place only in the XVIIth and XVIIIth centuries and acquired paradoxical forms in the middle of the XIXth century, when the finished product was decorated. Consequently, it can be assumed that the origins of the formation of the actual design terms fall precisely on this period. Trends of World Design of the second half of the XIXth - XXth centuries affected the peculiarities of Ukrainian design. In domestic science, the phenomenon of design and its terminology was generally ignored for a long time, and giving it the status of scientific branch occured primarily in aesthetic studies by V. Glazychev, L. Shchedrovitsky, L. Kagan, L. Novikova. Another group of researchers (R. Buchanan, J. Johns, E. Lazarev, Y. Lehenky, T. Maldonado, S. Migal, A. Mol, G. Simon) considers the design not within its internal laws and properties, but as a manifestation of the design culture as a whole.

The third stage (20-30's of the 20th century) involves purposeful terminological work, in particular the active work of the Institute of the Ukrainian Scientific Language of the Academy of Sciences (1921) on the formation of an independent Ukrainian language of science and technology. The need for Ukrainian-language dictionaries and textbooks is growing. Within a year (1918-1919) more than 20 terminological dictionaries were published in Ukrainian in different branches of knowledge. The aesthetic values created in those years, with all their ambiguity, controversy, will remain in the history of our culture. Historically, design began in the industry. Its interests were the design of individual industrial products, their complexes and ensembles and the production environment. The design, aimed at simultaneous and interrelated development of utilitarian and aesthetic parameters of a separate industrial product, got the name ,artistic design" in the Ukrainian terminology. The design is at the junction of two distinctive branches of human activity - technical and aesthetic creativity, 
and has a direct connection with both of them. It is considered a type of art or a special, specific type of technical aesthetic creativity. The main difficulty in disassembling the design as an independent activity is that it rarely exists in its pure form, but is accompanied by a decorative art, advertising techniques, stylization, and secondary imagery.

Traditionally, the design distinguishes three areas: design of industrial products, graphic design and design of the environment. It is possible to distinguish between the spheres of specific design: design-landscape, design, decorative and applied and design-public. The scope of the design should include the following subspecies: design management, design environment, landscape design, industrial design, textile design, costume design, graphic design, design of jewelry, futurodesign, stage design, television, theatrical sights, visor-design, phytodesign and some others, which have not had a clear definition yet. Summing up, it can be seen that design as artistic designing manifests itself in all spheres of activity, but each of them involves a different combination of form formation means.

The fourth stage (30's and 90's of the XXth century) is marked by the stagnation in the development of Ukrainian scientific terminology. In the postwar years, the development of design and its terminology system somewhat revived, although the reform of 1934 deprived institutes of artistic-industrial profile and, in general, the times of contempt for the theory of ,productive art" came. The first definitions of design appeared in the 1950's and were formulated primarily by theorists of art. The main task of design began to consider the development of recommendations to industry representatives on the range of products, its appearance. In such an interpretation it reflected the old ties of design with decorative and applied arts. Later, in the 1960's, when such an interpretation seemed to be too narrowly construed, it was complemented by a number of indicators that reflected design links with social production and consumption [1, p. 49]. Development of the terminology of design since the 1930's, in our opinion, is marked by the influence of extra-language factors (primarily political ones). The design terms (33\%) were fixed on designations of techniques, types of decor, elements of landscape design and ornaments.

The fifth stage (since 1991) - Ukraine became an independent state, the Ukrainian language is the state one. The need for vocational dictionar- 
ies and textbooks for the training of young specialists became acute [6, p. 1]. At this time there is the appearance of the term „design“ (,creative activity whose purpose is to determine the formal qualities of industrial products“ $[2$, p. 6]). ,Thanks to the dedicated work of specialists and with the participation of expert scientists in philology, an unprecedented fact of the development of more than 600 State Standards of Ukraine on „Terms and Definitions,, became possible, in 1996 the State Standard on Design and ergonomics was adopted. While reviewing the development of the Ukrainian terminology of design as a whole, it is necessary to distinguish between two tendencies: the first of them (20's and 30's) suggests orientation of the national terminology on the native-speaking soil, the avoidance of foreign words and their components. The second tendency implies maximum approximation of Ukrainian. Thus, the Ukrainian terminology of design is the result of centuries of development, the reflection of the world and domestic construction and architectural affairs, its formation clearly reflected the national specificity and international experience. In addition, the development of modern terminology of design was influenced by general tendencies of language development. The terminology of the design is characterized by a long history of development, which increases the importance of studying its terms, and today it remains the subject of in-depth enoho study.

\section{Список використаних джерел та літератури}

1. Аронов В. Р. Архитектура и дизайн / В. Р. Аронов. - М. : [б. и.], 1975. $-40 \mathrm{c}$.

2. Глазычев В. Л. Зарождение зодчества / В. Л. Глазычев. - М. : Стройиздат, 1983. - $126 \mathrm{~s}$.

3. Кутарева Л. В. Лексико-семантический способ образования научно-технических терминов / Л. В. Кутарева // Вопросы общего и славянского языкознания. - Днепропетровск : Днепропетровский ун-т. - 1976. C. $124-129$.

4. Лазарев Е. Н. Основы технической эстетики и художественного конструирования / Е. Н. Лазарев. - Ленинград : [б. и.], 1971. - 26 с. 
5. Наконечна Г. В. До історії унормування української науково-технічної термінології / Г. В. Наконечна // Мовознавство. - 1992. - № 6. - С. 41-47.

6. Тищенко О. Історія декоративно-прикладного мистецтва України (XIII-XVIII ст.) / О. Тищенко. - К. : Либідь, 1992. - 192 с.

7. Антонович С. А. Російсько-український словник-довідник з інженерної графіки, дизайну та архітектури / Є. А. Антонович, Я. В. Василишин, В. А. Шпільчак. - Львів : Світ, 2001. - 240 с.

8. Декоративно-ужиткове мистецтво: Словник: У 2 т. - Львів : Афіша, 2000. -T.1-2.

9. Ничкало С. А. Мистецтвознавство : Короткий тлумачний словник: Архітектура. Живопис. Скульптура. Графіка. Декоративно-ужиткове мистецтво / С. А. Ничкало. - Київ : Либідь, 1999. - 208 с.

10. Черных П. Я. Историко-этимологичекий словарь современного русского языка: В 2 т. / П. Я. Черных. - 3-е изд., стер. - М. : Русск. яз., 1999.

11. Этимологический словарь русского языка / Под. ред. Н. М. Шанского. - М. : Изд-во Московского ун-та, 1973.

\section{References}

1. Aronov V. R. Arkhitektura i dizayn / V. R. Aronov. - M. : [b. i.], 1975. -40 p.

2. Glazychev V. L. Zarozhdenie zodchestva / V. L. Glazychev. - M. : Stroyizdat, 1983. - $126 \mathrm{p}$.

3. Kutareva L. V. Leksiko-semanticheskiy sposob obrazovaniya nauchnotekhnicheskikh terminov//Voprosy obshchego i slavyanskogo yazykoznaniya.Dnepropetrovsk: Dnepropetrovskiy un-t. - 1976. - P. 124-129.

4. Lazarev E. N. Osnovy tekhnicheskoy estetiki i khudozhestvennogo konstruirovaniya / E. N. Lazarev. - Leningrad : [b. i.], 1971. - 26 p.

5. Nakonechna H. V. Do istoriyi unormuvannya ukrayins'koyi naukovotekhnichnoyi terminolohiyi / H. V. Nakonechna // Movoznavstvo. - 1992. - № 6. - P. 41-47.

6. Tyshchenko O. Istoriya dekoratyvno-prykladnoho mystetstva Ukrayiny (XIII-XVIII st.) / O. Tyshchenko. - K. : Lybid', 1992. - 192 p.

7. Antonovych Ye. A. Rosiys'ko-ukrayins'kyy slovnyk-dovidnyk z inzhenernoyi hrafiky, dyzaynu ta arkhitektury / Ye. A. Antonovych, Ya. V. Vasylyshyn, V. A. Shpil'chak. - L'viv : Svit, 2001. - 240 p.

8. Dekoratyvno-uzhytkove mystetstvo: Slovnyk: U 2 t. - L'viv : Afisha, 2000. - T.1-2. 
9. Nychkalo S. A. Mystetstvoznavstvo : Korotkyy tlumachnyy slovnyk: Arkhitektura. Zhyvopys. Skul'ptura. Hrafika. Dekoratyvno-uzhytkove mystetstvo / S. A. Nychkalo. - Kyyiv : Lybid', 1999. - 208 p.

10. Chernykh P. Ya. Istoriko-etimologichekiy slovar' sovremennogo russkogo yazyka: 13560 slov : V 2 t. / P. Ya. Chernykh. - 3-e izd., ster. - M. : Russk. yaz., 1999.

11. Etimologicheskiy slovar' russkogo yazyka/ Pod. red. N. M. Shanskogo.M. : Izd-vo Moskovskogo un-ta, 1973.

\section{Я. Г. Мар'янко,}

кандидат філологічних наук, доцент кафедри іноземних мов

Одеської державної академії будівництва та архітектури, вул. Дідріхсона, 4, м. Одеса, 65029, Україна, тел.: +380487233342, maryanko.yanina@gmail.com

\section{О. Ю. Зайцева,}

кандидат філологічних наук, доцент кафедри іноземних мов Одеської державної академії будівництва та архітектури, вул. Дідріхсона, 4, м. Одеса, 65029, Україна, тел.: +380487233342,

zayenka.57@gmail.com

\section{УКРАЇНСЬКИЙ ДИЗАЙН ЯК ОКРЕМА ГАЛУЗЬ ДЕКОРАТИВНО-ПРИКЛАДНОГО МИСТЕЦТВА ТА СТАНОВЛЕННЯ ЙОГО ТЕРМІНОЛОГІї}

Дослідження термінології будь-якої галузі неможливе без вивчення походження цієї галузі, іiі становлення, історії, характерних особливостей. Українська термінологія дизайну є цілісною системою мовних одиниць, серед яких розрізняємо власне дизайнерські найменування та номінативні елементи з інших споріднених галузей, зокрема сфери будівництва, архітектури i мистецтва. 
Ключові слова: термін, термінологія, науково-технологічна термінологія, терміносистема, дизайн.

\section{Я. Г. Марьянко, О. Ю. Зайцева \\ УКРАИНСКИЙ ДИЗАЙН КАК \\ ОТДЕЛЬНАЯ ОТРАСЛЬ ДЕКОРАТИВНО- ПРИКЛАДНОГО ИСКУССТВА И СТАНОВЛЕНИЕ ЕГО ТЕРМИНОЛОГИИ}

Исследование терминологии любой отрасли невозможно без изучения происхождения этой отрасли, ее становления, истории, характерных особенностей. Украинская терминология дизайна является целостной системой языковых единиц, среди которых различаем собственно дизайнерские наименования и номинативные элементы из других родственных отраслей, в частности сферы строительства, архитектуры и искусства.

Ключевые слова: термин, терминология, научно-технологическая терминология, терминосистема, дизайн.

Надійшла до редакиії 15.07.2017 p. 